\title{
AN ANALYSIS OF COMPOSITE DRIVE SHAFT USING ANSYS ACP
}

\author{
PNE NAVEEN ${ }^{1} \&$ R. BHASKARA REDDY ${ }^{2}$ \\ ${ }^{I}$ Research Scholar \& Assistant Professor, Department of Mechanical Engineering, Sankethika \\ Vidya Parishad, Visakhapatnam, Andhra Pradesh, India \\ ${ }^{2}$ Student, Department of Mechanical Engineering, Sankethika Vidya Parishad, \\ Visakhapatnam, Andhra Pradesh, India
}

\begin{abstract}
Almost all automobiles (at least those which correspond to design with a rear wheel drive and front engine installation) have transmission shafts. The weight reduction of the drive shaft can have a certain role in the general weight reduction of the vehicle and is a highly desirable goal, if it can be achieved without an increase in the cost and decrease in the quality and reliability.

In this paper, an automobile drive shaft is designed using ANSYS ACP workbench and analysis performed using ANSYS static structural workbench. Analysis preformed on 4 different materials which includes conventional structural steel and 3 different composite materials. E glass/Epoxy, High strength Carbon Epoxy (230GPA) and High Modulus Carbon Epoxy (395GPA). Results are compared and conclude High strength carbon is the optimum material for manufacturing the automobile drive shaft.

KEYWORDS: Driving Shaft, Composite Material \& ANSYS ACP
\end{abstract}

Received: Jul 31, 2018; Accepted: Aug 21, 2018; Published: Aug 27, 2018; Paper Id: IJMPERDOCT201815

\section{INTRODUCTION}

A driveshaft is a rotating shaft that transmits drive to the wheels. Drive shaft must operate through constantly changing angles between the transmission and axle. High quality steel (Steel SM45) is a common material for construction. Steel drive shafts are usually manufactured in two pieces to increase the fundamental bending natural frequency because the bending natural frequency of a shaft is inversely Proportional to the square of beam length and Proportional to the square root of specific modulus.

This work deals with the analysis of conventional steel shaft and 3 different composite shafts. Results proves that how beneficial is the replacement of a conventional steel drive shaft with E-Glass/ Epoxy High strength carbon/epoxy and High modulus carbon /epoxy composite drive shafts for an automobile application. This present work an attempt has been to estimate the deflection, stresses and natural frequencies under subjected loads using ANSYS ACP. A further comparison carried out for both conventional and composite shafts.

\section{DRIVE SHAFT COMPARISON}

\section{Demerits of Conventional Drive Shaft}

- They have less specific modulus and strength.

- Weight is high compared to composites. 
- Manufactured in Two pieces due to bending natural frequency.

- Corrosion resistance less

- $\quad$ Steel drive shafts have less damping capacity.

\section{Merits of Composite Drive Shafts}

- They have high specific modulus and strength.

- Weight is less compared to conventional drive shafts.

- The fundamental natural frequency of the carbon fiber composite drive shaft can be twice as high as that of steel.

- They have a high damping capacity hence they produce less vibration and noise.

- They have good corrosion resistance

- Introduction to ANSYS Composite Prep Post (ACP)

- ANSYS Composite Prep Post training is geared towards engineers who are designing and analyzing layered composites.

- Adding Composites Definitions to Assemblies

- Modelling Composite Stacking's and Orientations

- Understanding Product Performance

- Toward Manufacturing

- 3-D Models for Thick Composites

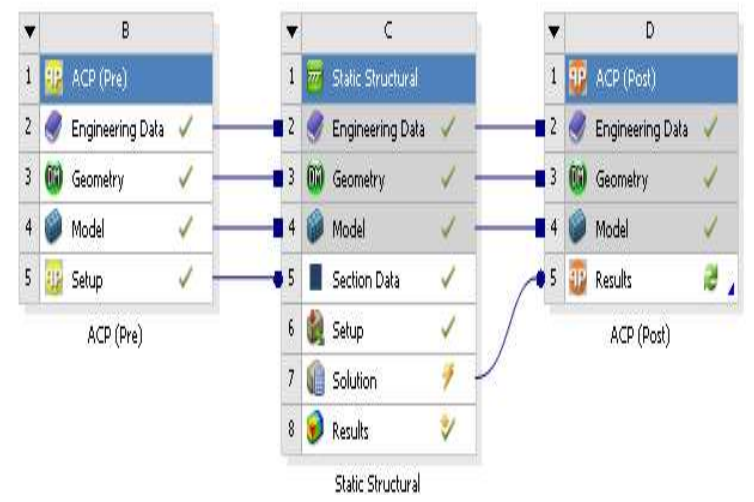

Figure 1: ANSYS ACP

Table 1: Specification of Drive shaft

\begin{tabular}{|l|l|l|l|}
\hline Parameter of the Shaft & Symbol & Value & Unit \\
\hline
\end{tabular}

\begin{tabular}{|l|c|c|c|}
\hline Outer Diameter & $\mathrm{D}_{\mathrm{O}}$ & 90 & $\mathrm{~mm}$ \\
\hline Inner Diameter & $\mathrm{D}_{\mathrm{i}}$ & 80 & $\mathrm{~mm}$ \\
\hline Length of the Shaft & $\mathrm{L}$ & 1200 & $\mathrm{~mm}$ \\
\hline Thickness of the shaft & $\mathrm{t}$ & 5 & $\mathrm{~mm}$ \\
\hline Ultimate Torque & $\mathrm{T} \max$ & 3500 & $\mathrm{Nm}$ \\
\hline Max speed of shaft & $\mathrm{N} \max$ & 6500 & $\mathrm{rpm}$ \\
\hline
\end{tabular}




\section{Material Properties of Structural Steel}

Name: Structural Steel

Model type: Linear Elastic Isotropic

Default failure criterion: Max von Misses Stress

Yield strength: $6.20422 \mathrm{e}+008 \mathrm{~N} / \mathrm{m}^{\wedge} 2$

Tensile strength: $7.23826 \mathrm{e}+008 \mathrm{~N} / \mathrm{m}^{\wedge} 2$

Elastic modulus: $2.1 \mathrm{e}+011 \mathrm{~N} / \mathrm{m}^{\wedge} 2$ Poisson's ratio: 0.28

Mass density: $7600 \mathrm{~kg} / \mathrm{m}^{\wedge} 3$

Shear modulus: $7.9 \mathrm{e}+010 \mathrm{~N} / \mathrm{m}^{\wedge} 2$

Thermal expansion coefficient: $1.3 \mathrm{e}-005$ /Kelvin

\section{Material Properties of Epoxy E-Glass}

Name: Epoxy E-Glass Grade: G-10 Normalized To 60\% Fibre Volume

Model Type: Orthotropic Elasticity

Default Failure Criterion: Max Von Misses

Density: $2000 \mathrm{Kg} / \mathrm{M}^{\wedge} 3$

Ply Type: Regular

Mesh Sizing: 10mm

No of Layers: 5

Stacking Sequence: 0-45-90-45-0

Table 2: Material Properties of Epoxy E-Glass

\begin{tabular}{|l|c|c|c|c|}
\hline \multicolumn{1}{|c|}{ Property } & $\mathbf{X} / \mathbf{X Y}$ & Y/YZ & Z/XZ & UNITS \\
\hline Young`S Modulus & 45000 & 10000 & 10000 & $\mathrm{Mpa}$ \\
\hline Possions Ratio & 0.3 & 0.4 & 0.3 & - \\
\hline Shear Modulus & 5000 & 3846.2 & 5000 & $\mathrm{Mpa}$ \\
\hline Tensile Stress & 1100 & 35 & 35 & $\mathrm{Mpa}$ \\
\hline Compressive Stress & -675 & -120 & -120 & $\mathrm{Mpa}$ \\
\hline Shear Stress & 80 & 46.154 & 80 & $\mathrm{Mpa}$ \\
\hline
\end{tabular}

\section{Material Properties of Epoxy Carbon 230 Gpa Prepeg}

Name: High Strength Epoxy Carbon 230 Gpa Prepeg

Grade: T300 Normalized To 60\% Fibre Volume

Model Type: Orthotropic Elasticity

Default Failure Criterion: Max Von Misses 
Density: $1490 \mathrm{Kg} / \mathrm{M}^{\wedge} 3$

Ply Type: Regular

Mesh Sizing: $10 \mathrm{~mm}$

No of Layers: 5

Stacking Sequence: 0-45-90-45-0

Table 3: Material Properties of Epoxy Carbon 230 Gpa Prepeg

\begin{tabular}{|l|c|c|c|c|}
\hline \multicolumn{1}{|c|}{ Property } & X/XY & Y/YZ & Z/XZ & UNITS \\
\hline Young`S Modulus & 121000 & 8600 & 8600 & Mpa \\
\hline Possions Ratio & 0.27 & 0.4 & 0.27 & - \\
\hline Shear Modulus & 4700 & 3100 & 4700 & Mpa \\
\hline Tensile Stress & 2231 & 29 & 29 & Mpa \\
\hline Compressive Stress & -1082 & -100 & -100 & Mpa \\
\hline Shear Stress & 60 & 32 & 60 & Mpa \\
\hline
\end{tabular}

\section{Material Properties of Epoxy Carbon 395 Gpa Prepeg}

Name: High Modulus Epoxy Carbon 395 Gpa Prepeg

Grade: M40j Normalized To 60\% Fibre Volume

Model Type: Orthotropic Elasticity

Default Failure Criterion: Max Von Misses

Density: $1540 \mathrm{Kg} / \mathrm{M}^{\wedge} 3$

Ply Type: Regular

Mesh sizing: $10 \mathrm{~mm}$

No of Layers: 5

Stacking Sequence: 0-45-90-45-0

Table 4: Material Properties of Epoxy Carbon 395 Gpa Prepeg

\begin{tabular}{|l|c|c|c|c|}
\hline \multicolumn{1}{|c|}{ Property } & $\mathbf{X} / \mathbf{X Y}$ & $\mathbf{Y} / \mathbf{Y Z}$ & $\mathbf{Z} / \mathbf{X Z}$ & UNITS \\
\hline Young`S Modulus & 209000 & 9450 & 9450 & $\mathrm{Mpa}$ \\
\hline Possions Ratio & 0.27 & 0.4 & 0.27 & - \\
\hline Shear Modulus & 5500 & 3900 & 5500 & $\mathrm{Mpa}$ \\
\hline Tensile Stress & 1979 & 26 & 26 & $\mathrm{Mpa}$ \\
\hline Compressive Stress & -893 & -139 & -139 & $\mathrm{Mpa}$ \\
\hline Shear Stress & 100 & 50 & 100 & $\mathrm{Mpa}$ \\
\hline
\end{tabular}

\section{Modelling In ACP}

- $\quad$ Start ANSYS workbench and drag ACP (Pre) to project schematic.

- $\quad$ Select required material from engineering data.

- Enter into Geometry and design desired profile at $0 \mathrm{~mm}$ thickness. 
- Next, open Model cell, assign material, $1 \mathrm{~mm}$ thickness and complete mesh.

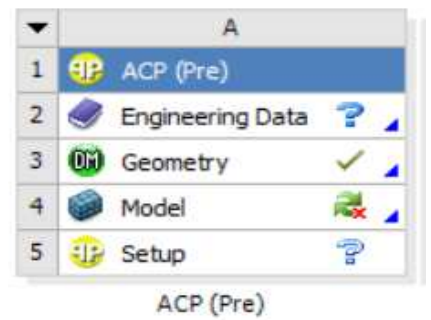

Figure 2: Modelling in ACP

- Open setup, select and create Fabrics under Material Data.

- Add new rosette to model and define a rosette type as parallel.

- Create new oriented element set using rosette and elements set as required.

- Create Ply Group with the help of oriented elements and enter an angle, no layers.

- Create Ply with different angles as required.

- Update the model and convert to a solid model.

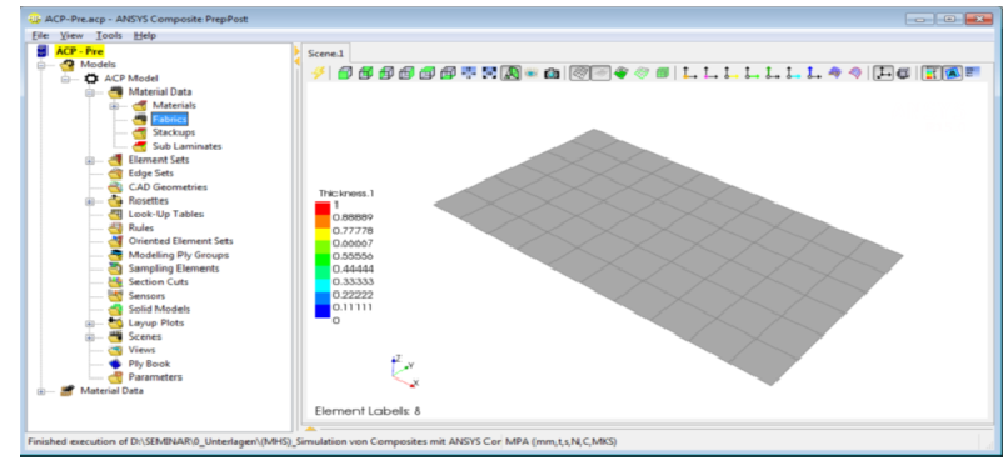

Figure 3: ACP workspace

- Drag and drop static structural workbench to project schematic and connect setup cell from ACP (Pre) to model cell in static structural, select option "transfer solid data".

- Open the model cell in static structural and Check the geometry.

\section{Structural Analysis in ANSYS}

- Open model cell in static structural and select static structural from model tree.

- Apply constraint on one end of the shaft.

- Apply Moment force of 3500N-m on the other end of the shaft.

- Select Total deformation, Von misses, shear strain from Solution option and execute the solution.

- At project schematic right click on solution cell from static structural and select "Transfer data" -> "Modal".

- Open modal workbench and select total deformation option from solution part. 
- Execute the solution and evaluate the results.

\section{LOADS AND CONSTRAINTS}

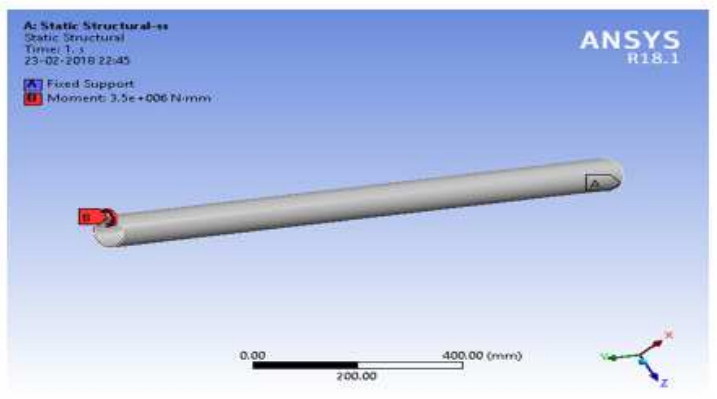

Figure 4: Loads and Constraints of Structural Steel

RESULTS OF STRUCTURAL STEEL

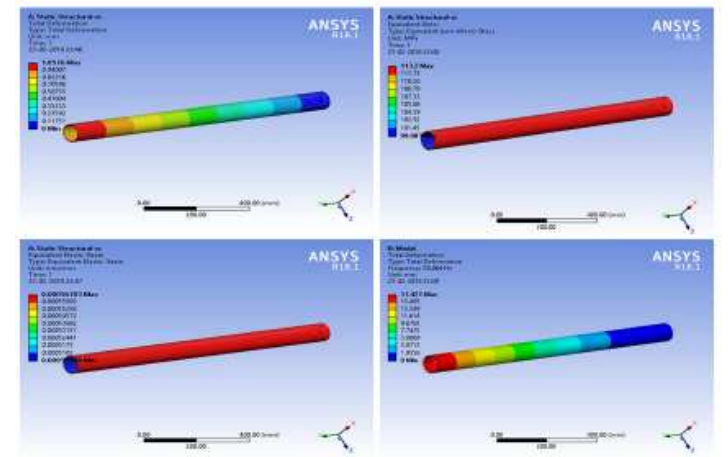

Figure 5: Results of Structural Steel

\section{DESIGNED SHAFT IN ACP}

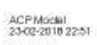

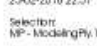

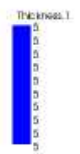

DESIGNING IN ACP

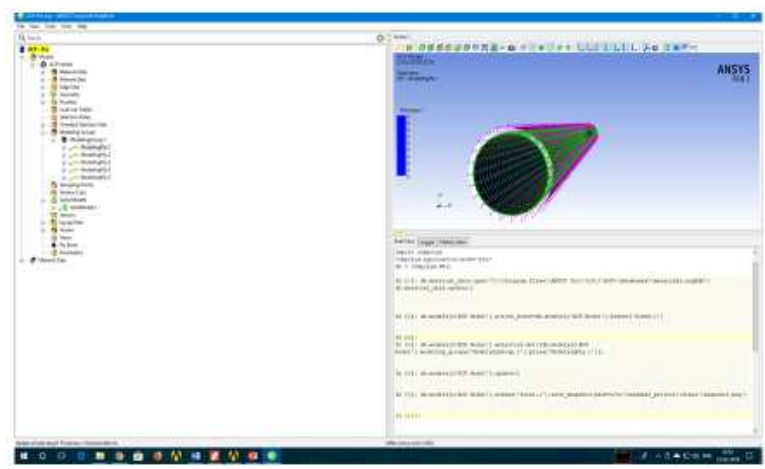

Figure 6: Designing in ACP

LOADS AND CONTRAINTS

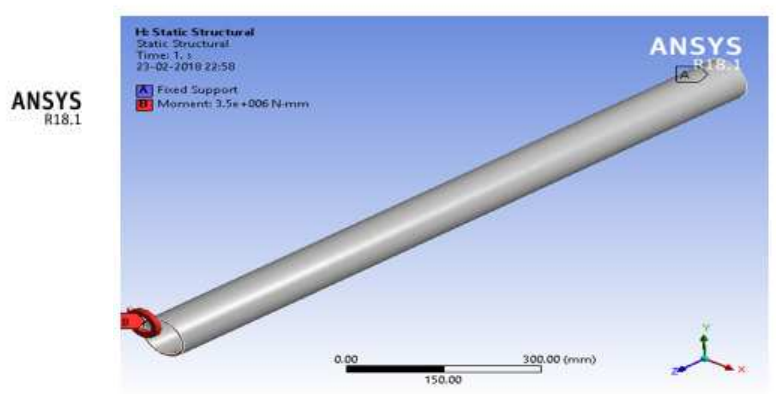

Figure 8: Loads and Constraints of E-Glass

Figure 7: Designed Shaft in ACP 
RESULTS OF E-GLASS
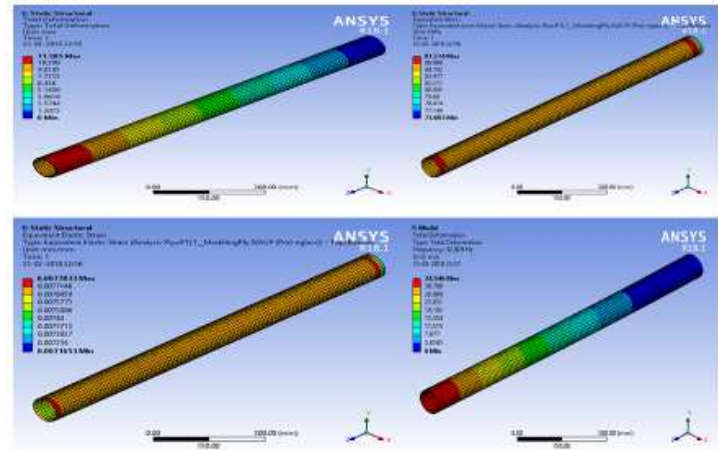

Figure 9: Results of E Glass

\section{RESULTS OF HIGH STRENGTH CARBON}
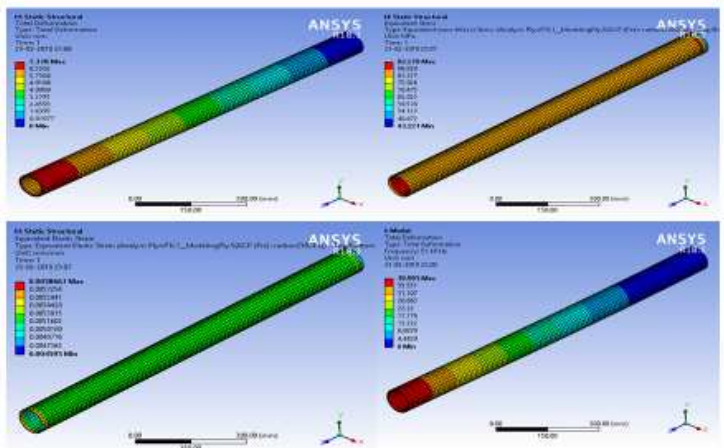

Figure 10: Results of High Strength Carbon

\section{RESULTS OF HIGH MODULUS CARBON}
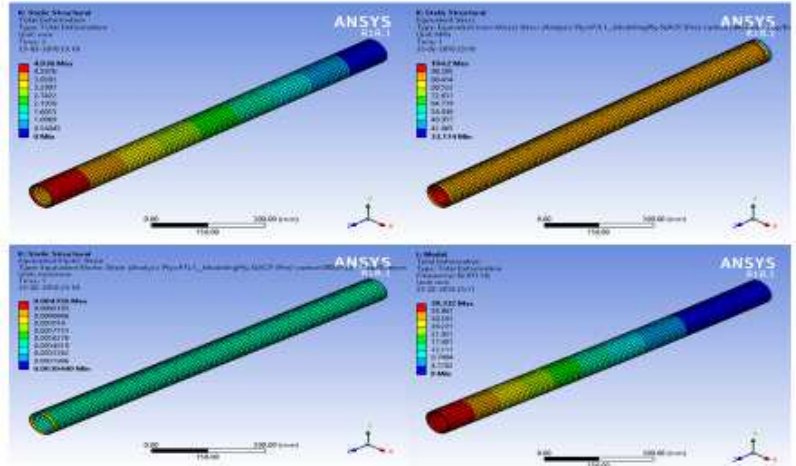

Figure 11: Results of High Modules Carbon

\section{RESULTS}

Table 5: Results

\begin{tabular}{|c|c|c|c|c|c|}
\hline $\begin{array}{l}\text { Material } \\
\text { Name }\end{array}$ & \begin{tabular}{|c|} 
Weight \\
(Kg)
\end{tabular} & \begin{tabular}{|c|} 
Total \\
Deformation $\mathrm{mm}$
\end{tabular} & $\begin{array}{c}\text { Elastic Strain } \\
(\mathrm{mm} / \mathrm{mm})\end{array}$ & $\begin{array}{c}\text { Von Misses } \\
(\mathrm{MPa})\end{array}$ & $\begin{array}{c}\text { Frequencies } \\
(\mathbf{H z})\end{array}$ \\
\hline $\begin{array}{l}\text { Structural } \\
\text { steel }\end{array}$ & 13.101 & 1.0576 & 56703 & 113.2 & $\begin{array}{l}1.54 .064 \\
2.324 .19 \\
3.626 .03 \\
4.853 .65\end{array}$ \\
\hline $\begin{array}{l}\text { E- } \\
\text { glass/Epoxy }\end{array}$ & 13.101 & 1.0576 & 0.0077833 & 87.274 & $\begin{array}{l}1.32 .929 \\
2.197 .73 \\
3.372 .70 \\
4.520 .16\end{array}$ \\
\hline $\begin{array}{l}\text { High } \\
\text { Strength } \\
\text { Carbon }\end{array}$ & 2.486 & 7.37 & 0.0058667 & 92.279 & $\begin{array}{c}1.51 .14 \\
2.306 .22 \\
3.535 .9 \\
4.801 .27 \\
\end{array}$ \\
\hline $\begin{array}{l}\text { High } \\
\text { Modulus } \\
\text { carbon }\end{array}$ & 2.57 & 4.936 & 0.004356 & 104.2 & $\begin{array}{c}1.62 .81 \\
2.375 .86 \\
3.643 .05 \\
4.981 .87 \\
\end{array}$ \\
\hline
\end{tabular}




\section{CONCLUSIONS}

Based on the results it is concluded that High strength carbon with reduced weight shows deformationas $7.37 \mathrm{~mm}$, elastic strain of $0.0058667 \mathrm{~mm}$, von misses stress of $92.279 \mathrm{MPa}$ at a frequency of $(51.15,306.22,535.9,801.27)$ is optimised when compared to other composite materials and conventional structural steel.

\section{REFERENCES}

1. Bhirud Pankaj Prakash, bimlesh Kumar Sinha Analysis Of Drive Shaft Department of Mechancial, PG Student, J. T. M. Mahajan college of Engg, Faizpur,

2. Design And Analysis Of Composite Drive Shaft V. S. Bhajantri1, S. C. Bajantri

3. Design and Analysis of Composite Drive Shaft for Automotive Application G. Kaviprakash PG Scholar, Dept. of Mechanical Engineering, Anna University Regional office - Madurai, Madurai, India

4. Design and Analysis of Composite Drive Shaft for Automotive ApplicationS. Mohan and M. Vinoth The High Strength Carbon composite drive shafts

5. Tiwari, B., \& Sharma, U. Synthesis And Characterization Of Titanium Metal Carbon Nano Tubes.

6. Design And Analysis Of Composite Drive Shaft A. Sridhar Dr. R. Mohan, R. Vinoth Kumar

7. Design, Comparison and Analysis of a Composite Drive Shaft for an Automobile Arun Ravi The High Strength Carbon composite drive shafts 